The Formosa Case: A Step

Forward on the Acceptance

of Citizen-Collected

\section{Evidence in
Litigation?}

\author{
ANNA BERTI SUMAN (D) \\ SVEN SCHADE D
}

*Author affiliations can be found in the back matter of this article
CITIZEN SCIENCE: THEORY AND PRACTICE
CASE STUDIES

\section{] $\mathrm{u}[$ ubiquity press}

\begin{abstract}
In June 2019, a landmark court decision (San Antonio Bay Estuarine Waterkeeper, et al. v. Formosa Plastics Corporation, et al., hereafter referred to as the Formosa ruling) was issued in Texas, where a judge found a petrochemical company liable for violating the United States Clean Water Act. The case-initiated by a civic group-was mostly built on citizen-collected evidence involving volunteer observations of plastic pellets, powder and flakes in the water over a considerable time span. The contamination could not be proven through existing data held by competent authorities because the company never filed any record of pollution (Formosa ruling, XI.A, p. 17). ${ }^{1}$ In contrast to the majority of environmental pollution cases to date, the monitoring and data collection for this case was conducted by local residents who gathered a wealth of evidence of plastic pollution in water. Through a traditional case law and text analysis of the Formosa ruling, complemented by the analysis of surrounding communications, we explore why and how citizen-collected evidence was admitted and influenced the judge's ruling. Although the case has some unique features, we identify possible arguments and lessons learned for other citizen-run monitoring initiatives, to strengthen their voice within environmental litigation. We close by suggesting an avenue for future research-especially in the European context, where the discussion is still in its infancy.
\end{abstract}

CORRESPONDING AUTHOR:

\section{Anna Berti Suman}

The Tilburg Institute for Law, Technology and Society, Tilburg University, NL anna.bertisuman@gmail.com

\section{KEYWORDS:}

citizen-collected evidence; citizen science; environmental litigation; environmental justice; plastic pollution

\section{TO CITE THIS ARTICLE:}

Berti Suman, A and Schade, S. 2021. The Formosa Case: A Step Forward on the Acceptance of Citizen-Collected Evidence in Environmental Litigation? Citizen Science: Theory and Practice, 6(1): 16, pp. 1-13. DOI: https://doi.org/10.5334/cstp.367 


\section{INTRODUCTION BACKGROUND}

In June 2019, a landmark court decision (San Antonio Bay Estuarine Waterkeeper, et al. v. Formosa Plastics Corporation, et al., hereafter referred to as the Formosa ruling) was issued in Texas, United States (US), in which a judge found a petrochemical company-the Formosa Plastics Corporation-liable for violating the US Clean Water Act. When we refer in this article to the conviction of Formosa Plastics Corporation or we use the term 'the company', we mean the conviction both of Formosa Plastics Corporation, Texas, and Formosa Plastics Corporation, US, which are two different entities against which the case was filed. The civil lawsuit was filed under the 'citizen suit authority' as provided by Section 505 of the Clean Water Act, which regulates if and when a citizen can sue a polluter. A citizen suit is a lawsuit by a private citizen to enforce a statute. The case was initiated by local residents and fishers organized under the civic group San Antonio Bay Estuarine Waterkeeper (hereinafter, the

\begin{tabular}{|c|c|}
\hline Case Name & San Antonio Bay Estuarine Waterkeeper, et al. v. Formosa Plastics Corporation, et al. \\
\hline Type of litigation & $\begin{array}{l}\text { Civil law proceeding, lawsuit against (alleged) polluters; litigation brought under the citizen suit authority } \\
\text { provided by Section } 505 \text { (b) of the US Clean Water Act. }\end{array}$ \\
\hline Scale & Local. \\
\hline Identification & Case 6:17-cv-00047 Document 155 Filed on 06/27/19. \\
\hline Country & US (Texas). \\
\hline Court & US District Court for the Southern District of Texas, Victoria division. \\
\hline Plaintiffs & $\begin{array}{l}\text { Environmental association (San Antonio Bay Estuarine Waterkeeper) part of a larger non-profit, and an } \\
\text { individual plaintiff, Diane Wilson. }\end{array}$ \\
\hline Defendants & $\begin{array}{l}\text { Formosa Plastics Corporation, Texas, and Formosa Plastics Corporation, US, petrochemical companies owned } \\
\text { by a Taiwanese corporation. }\end{array}$ \\
\hline Advocacy type & A dedicated local resident organizing citizens' efforts. \\
\hline Status & $\begin{array}{l}\text { Final ruling in June 2019; the court approved the consent decree negotiated by the parties in November } \\
\text { 2019, endorsing the settlement, which is being implemented. }\end{array}$ \\
\hline Alleged violations & $\begin{array}{l}\text { Repeated violations of the US Clean Water Act by not complying with Texas Pollutant Discharge Elimination } \\
\text { System (TPDES, a regulatory program to control pollutants discharges into waters) Permit \#WQ0002436000 } \\
\text { by discharging floating solids (plastic pellets, powder and flakes); violations of reporting duties according to } \\
\text { the Permit, to federal and state statutes ( } 33 \text { USC. } § 1318 \text { (b), and to the Texas Water Code. }\end{array}$ \\
\hline Type of evidence submitted & $\begin{array}{l}\text { Photos, videos, and several containers with plastics collected by the citizens, expert testimony } \\
\text { and admissions of defendants, factual testimony of citizens, findings of the Texas Commission on } \\
\text { Environmental Quality and Formosa audits. }\end{array}$ \\
\hline $\begin{array}{l}\text { Methodology/eventual link to } \\
\text { standard operating procedures } \\
\text { (SOPs) }\end{array}$ & $\begin{array}{l}\text { Collection of 2,428 samples of plastics on more than } 500 \text { distinct days on Lavaca Bay, and thousands of } \\
\text { photos and videos documenting unlawful discharge of plastic pellets, powder and flakes; } \\
\text { see https://www.nomorenurdles.org/category/weekly-water-keeper-plastic-reports/ and https://www. } \\
\text { nomorenurdles.org/water-monitoring-preserving-evidence/ for operating procedures. }\end{array}$ \\
\hline Period/duration of observations & Discharges were observed and evidence collected between January 31, 2016 and March 12, 2019. \\
\hline $\begin{array}{l}\text { Number of people involved in the } \\
\text { data collection }\end{array}$ & 4 key volunteers and a crowd of supporters. \\
\hline $\begin{array}{l}\text { Reaction of the court/defendant } \\
\text { to civic evidence }\end{array}$ & Citizen-collected evidence was not contested by the court nor by the company. \\
\hline Decision issued & $\begin{array}{l}\text { Issuing of monetary relief and injunction against Formosa. In the subsequent settlement between the } \\
\text { parties, Formosa agreed to monetary relief amounting to } \$ 50 \text { million in mitigation payments. The court } \\
\text { approved the settlement and remedy contained in the consent decree. }\end{array}$ \\
\hline $\begin{array}{l}\text { Top winning factors for the } \\
\text { acceptance of citizen science } \\
\text { evidence }\end{array}$ & $\begin{array}{l}\text { Relatively simple type of evidence; application of qualitative legal standard that did not require quantified } \\
\text { measurement ("more than trace amounts", Formosa ruling, IX, p. 15); the amount of reciprocal } \\
\text { corroborating evidence submitted; a dedicated person organizing citizens' efforts; rigorous data collection } \\
\text { conducted over years and supported by experts; the availability of free legal counsel through Texas } \\
\text { RioGrande Legal Aid, which also financed expert witnesses; "a talented team of experienced lawyers" } \\
\text { (Again suggestion of the chief lawyer). }\end{array}$ \\
\hline Evidentiary rulings & $\begin{array}{l}\text { Citizen-collected evidence was not challenged in court. Related plaintiffs' expert testimony was found to } \\
\text { meet the Daubert standard for admissibility of scientific evidence, after being challenged by the company. }\end{array}$ \\
\hline
\end{tabular}

Table 1 Summary of the key elements of the case. 
plaintiffs). ${ }^{2}$ Remarkably, the plaintiffs built their claims mostly on citizen-collected evidence that involved volunteer observations of plastic pellets (i.e., "floating debris and suspended solids" as defined by the Formosa ruling, IV, p. 5, also informally called "nurdles", Ahmed 2019), powder and flakes in the water over years. Table 1 below summarizes the key elements of the case. In the supplemental file, Appendix 1: "Summary of the case," a short overview of the case is also provided.

Three main aspects characterize the context of the Formosa ruling. First, the contamination could not be proven through existing data held by competent authorities because the company never reported episodes of pollution to such authorities, nor did the Texas Commission on Environmental Quality (TCEQ) have record of them (Formosa ruling, XI.A, p. 17). Therefore, the action of the citizens responded to an enforcement gap due to the failures of the company and of the competent agency.

Second, in contrast to the majority of environmental pollution cases to date, the monitoring and data collection in this case was conducted by local residents (Ahmed 2019). Such evidence-not questioned by the court nor by the company - was crucial to prove Formosa's wrongdoings and to obtain a positive ruling. Especially in human rightsbased approaches to environmental litigation, it is not unusual that data collected by the plaintiffs becomes part of the procedure, but the novelty in this case is in the key role that the citizen-submitted evidence played in proving Formosa's responsibility. Also, as the plaintiff's chief attorney, Amy Johnson, stressed in a communication with us, this case is rather novel for the US landscape of environmental enforcement, although it is not the first court admission of public evidence grounding liability for environmental violations (Emmett Environmental Law and Policy Clinic 2019). Citizen-collected evidence thus filled a knowledge gap that could have eventually prevented institutional enforcement.

Lastly, the citizen-collected evidence was of an astonishing quantity, spread over years of monitoring, which easily convinced the court-in conjunction with other evidence-of the violation of Formosa's Texas Pollutant Discharge Elimination System (TPDES) Permit \#WQ0002436000 (based on a qualitative legal standard, i.e., plastics discharge into water in "more than trace amounts" (Formosa ruling, IX, p. 15). The TPDES, in which framework the Permit was issued, is a program aimed to regulate and control discharges of pollutants to surface waters. The significance of the case arises in large part from the public messaging around the case, which highlighted the role of the coordinated and granular monitoring efforts by local residents to demonstrate Formosa's Permit violations.

\section{LEGAL SIGNIFICANCE OF THE CASE}

At a general level, in the US, plaintiffs can submit evidence that they have gathered themselves. Such data are scrutinized by courts using traditional categorization methods for different types of plaintiff submissions (Environmental Law Institute 2002). In this case, of interest is how the court applied procedural rules on admissible evidence (i.e., those rules relating to the procedure used by courts to administer substantive (aw) to the citizencollected evidence.

Abstracting from the specific case, instances such as the Formosa litigation raise the question under which conditions can citizen-collected data be accepted in courts as legal evidence of environmental wrongdoing? This inquiry is especially timely considering the increase in citizen science (i.e., "the active public involvement in scientific research," Irwin 2018) associated with growing societal education levels and technical progress (Smith 2014; Irwin 2018), and because of the pervasive role that science in general plays in courts. It is worth noting that, in the specific case at hand, we are discussing a distinctive type of citizen science entailing a simple data collection (only picking plastics and taking pictures, and not involving sophisticated monitoring). We stress in the limitation section that (some of) our conclusions may not apply to more sophisticated forms of public evidence. Furthermore, there are a number of caveats that must be considered in extending these lessons to European judicial settings, where to date there has been no case similar to the Formosa ruling.

To answer the overarching question of the conditions under which citizen-collected data can be accepted in courts as legal evidence of environmental wrongdoing, we target our case analysis to a set of more detailed enquiries, namely:

1) Which types of evidence counted as citizen science in the Formosa litigation?

2) How did the judge classify this evidence?

3) Against which standards did the judge assess the admissibility and credibility of the evidence submitted by the plaintiffs?

4) How large was the role played by this evidence in the judge's decision, considering that the plaintiffs also presented agency findings, company audits, and testimony by qualified expert witnesses?

Based on the case analysis, we identify arguments that support the consideration and use of citizen-collected data in grounding environmental judgments, bearing in mind the context-dependency and specificities of the case at hand. Overall lessons are extracted from the ruling to support any civic group that wants to be listened to in environmental 
litigation. In conclusion, we stress the limitations of this study and draft a future research agenda.

\section{STATE OF THE ART}

Research on the potential of citizen science to be accepted by courts and to influence court decisions is still in its infancy. The few actors in the current debate are primarily focused on the US. They include the Citizen Science Association's Law and Policy Working Group, the Harvard Law School's Emmett Environmental Law and Policy Clinic, the Environmental Law Institute, and the US Environmental Protection Agency (EPA). ${ }^{3}$ Researchers have begun to inspect the US legal framework regulating the admissibility of plaintiffs' data and have verified the applicability of these rules to citizen science (Emmett Environmental Law and Policy Clinic 2019). Yet, these researchers also acknowledge that citizen science groups may struggle to meet the standards for court admissibility. US agencies have issued regulations and statutes on what they consider credible data, limiting what kinds of data from volunteers can be accepted to trigger official law enforcement (Emmett Environmental Law and Policy Clinic 2019, p. 16). Clearly, the US legislative and scientific debate on the issue is growing, although this literature has rarely been translated in terms and formats accessible to interested communities.

In the US, citizen-collected evidence may, in some circumstances, be admitted as fact evidence rather than opinion evidence. In the Formosa litigation, there seems to be a matter of factual evidence as the citizens could prove the fact that plastic pellets, powder and flakes from the Formosa plant were found in jurisdictional waters. ${ }^{4}$ In other instances, citizen-gathered evidence may be admitted as court evidence under the category of lay opinion testimony as opposed to expert opinion, which instead relies on specialized knowledge.

European scholarship on citizen science emphasizes the learning potential of the practice for volunteers (Becker et al. 2013; Den Broeder et al. 2017). Conversely, scarcer attention has been devoted to its potential in judicial and extra-judicial settings. The reliance on public evidence to offer (missing) evidence in environmental litigation seems mostly underestimated, although scholars have stressed the evidence-generation potential of volunteered geospatial data (Gutiérrez 2018) and their possible use for environmental justice action (Haklay and Francis 2018).

At the institutional level, the European Commission $(E C)$ has started to recognize the promises of using citizen-operated technologies to combat environmental crimes. ${ }^{5}$ The Communication COM(2017)312 stressed the potential of citizen science in streamlining environmental reporting. The EC's Joint Research Centre $(J R C)^{6}$ supported a study on the use of citizen science for environmental policy (Bio Innovation Service 2018) based on an inventory of $500+$ cases. ${ }^{7}$ The study stresses that the use of citizen science in compliance assurance and enforcement actions is currently low and scarcely researched at the European level. Furthermore, both the EC and the Member States have not yet regulated the field. This actually gives rise to a legislative vacuum, and is a missed opportunity for citizen science.

Overall, compared to the US experience on the topic, both at an applied level (existing case law) and in terms of academic studies, Europe is lagging behind. Researchers and especially legal scholars active on the topic are few globally, but especially in Europe (with some exceptions such as the ongoing Sensing for Justice project). ${ }^{8}$ This contribution, by extracting lessons from a successful case of judicial uptake of citizen science data, will develop reflections that could support citizens around the world in entering environmental litigation, despite recognizing the difficulty in drawing generalizable conclusions.

\section{METHODS}

We developed a case law analysis focusing on a single case, complemented by review of academic and grey literature, discussing the use of citizen science in court from both a US and a European perspective. We inspected the Formosa ruling through text analysis, targeting overall arguments and the use of specific words. We complemented this study with an inquiry into communications (such as newspaper articles, blog posts, and group discussions) that accompanied the ruling, to understand how the case was received by interested communities. Furthermore, we benefitted from the expert consultancy of two US citizen science and environmental law specialists. We also discussed our work with a spokesperson for the Formosa case plaintiffs and with attorney Johnson, who provided important insights into the ruling. Overall, this work can be regarded as a case study as it offers evidence-based reflections on the case outcomes and implications for scholars, practitioners, and interested communities.

\section{RESULTS OF THE CASE ANALYSIS GROUNDS FOR THE PLAINTIFFS' CLAIMS}

The plaintiffs in the case were interested citizens represented by the San Antonio Bay Estuarine Waterkeeper, an association whose mission is to preserve local wetlands and waterways, and environmental activist Sylvia Diane Wilson. Resorting to the citizen suit authority as provided by Section 505 of the Clean Water Act, they sued in 
court Formosa Plastics US and Texas, two petrochemical companies owned by a Taiwanese corporation. Thus, different from litigation against public authorities, here the plaintiffs' strategy was to directly sue a private actor. The suit was filed in the US District Court for the Southern District of Texas, Victoria division. The district court represents the lowest level of federal court, also known as trial court or court of first instance, as opposed to an appellate court, or court of appeals.

The grounds on which the plaintiffs built the ruling (i.e., the foundations of their claims) were that the company violated Texas laws and the US Clean Water Act as well as its environmental permits for years by dumping millions of plastic pellets, powder and flakes into Cox Creek and Lavaca Bay, Texas. These plastic materials are known to be particularly dangerous as they can poison fish and other wildlife that ingest them. Thus, the plaintiffs referenced national and state law, as well as specific permits, to identify Formosa's violations. The exceeding of legal limits was the first violation of the company alleged by the plaintiffs.

The TPDES Permit \#WQ0002436000 indeed allows Formosa to discharge wastewater (after treatment) and stormwater into Lavaca Bay and into Cox Creek, pursuant to the Texas Water Code and the Clean Water Act. The Permit provides that plastic may be discharged in "trace amounts," i.e., a very small, negligible, and barely discernible quantity of a constituent. It should be noted that this is a standard term in many permits, rather than one specifically targeted at plastic discharges.

Formosa was alleged not to be in compliance with the Permit due to discharge of plastics in quantities substantially "more than trace amounts" (Formosa ruling, IX, p. 15). Actually, the plaintiffs did allege persistent discharge, but they did not have to demonstrate persistent violations to have a Permit violation recognized. A discharge of more than trace amounts was sufficient, as it was a matter of applying a qualitative legal standard (a "narrative standard," according to Johnson) that did not require quantified measurement. Formosa denied any illegal dumping, arguing that its releases of plastic were under the limits allowed by its Permit. The company offered a theory that explained how it could discharge plastic from various outfalls and still be within the trace amount restriction. However, Formosa's own filings admitted that the Texas Commission on Environmental Quality (TCEQ) disagreed with this approach.

The plaintiffs argued, and the judge confirmed, that the company never filed any record of pollution with the TCEQ. Therefore, the local residents had to mobilize themselves and perform much of the record keeping and data collection, patrolling Lavaca Bay and Cox Creek by kayak and collecting evidence of plastic pollution in water. This differs from most environmental pollution cases, which are based on already-documented pollution. This failure to properly report contamination was the second violation at issue.

In this sub-section, we focused exclusively on the ground for the plaintiffs' suit. In the supplemental file, Appendix 3 provides a "Focus on standing of the plaintiffs;" Appendix 4 offers an "Insight into the "citizen suit authority;" Appendix 5 zooms in on the "Representation [of] the plaintiffs in the trial."

\section{THE JUDGE'S DECISION}

\section{Formosa's conviction}

The lawsuit, filed in 2017, led to a ruling delivered in 2019. Thus, the decision was relatively swift. First, the court affirmed to have jurisdiction on the case (Formosa ruling, III, p. 3) against Formosa's argument that challenged the plaintiffs' standing to bring the suit. Second, the judge found, with a declaratory judgment (i.e., a legally binding ruling defining and outlining the rights and obligations of each party), that Formosa had violated and kept violating its TPDES Permit and consequently the Clean Water Act, which makes unlawful the discharge by any person of any pollutant that is not discharged pursuant to a permit. The violations were said to be "enormous" and the company was said to be a "serial offender" (Formosa ruling, XI, p. 17), especially based on evidence of unlawful discharges documented by the plaintiffs and-to a smaller degreeon evidence of prior state enforcement submitted by the plaintiffs. The ruling indeed also noted that the US EPA had fined the company already multiple times for breaches of pollution regulations.

The judge followed a series of key steps in defining Formosa's liability (Formosa ruling, IV, from p. 4). Overall, Texas rules prohibit the discharge of "floating debris and suspended solids" into surface waters (Formosa ruling, IV, p. 5). Formosa's Permit did not cover the discharges of the company, which thus violated Texas rules and the Clean Water Act. Furthermore, the Permit also requires Formosa to report in writing and within 24 hours any incompliance that may endanger health, safety, and the environment. The ruling notes "evidence shows that Formosa has never reported a single discharge of floating solids to TCEQ" (Formosa ruling, XI, p. 17). To verify violations of permits, the TCEQ conducts inspections from time to time utilizing "visual sightings" (Formosa ruling, XI, p. 17) and photographs (which is similar to what the local residents did). The plaintiffs informed us that their complaints often spurred the TCEQ to conduct visual sightings of their own, establishing a precedent for citizens acting in a warning role in support of compliance. 


\section{Zooming into the evidence}

The court based its ruling on a combination of evidence from a number of sources, including citizen-collected evidence that corroborated other submitted evidence of Formosa's violations. The plaintiffs' evidence indeed reinforced itself (the word "confirm" is often used in the ruling in relation to the various pieces of evidence). Yet the ruling does not explicitly discuss the relationship between the pieces of evidence. According to a plaintiff and attorney Johnson, only this combination of evidence won the case. Citizencollected evidence was key to prove the magnitude of the violations, but the citizens' data alone was not enough; key experts and testimony admissions were fundamental. Overall, the plaintiffs' evidence featured:

- "Photographs, videos, and 30 containers containing 2,428 samples of plastics in gallon zip lock bags and plastic bottles of plastic pellets" (Formosa ruling, VI, p. 8) that the San Antonio Bay Estuarine Waterkeeper collected on more than 500 distinct days on Lavaca Bay between January 31, 2016 and March 12, 2019 (Formosa ruling, VI, p. 10). One plaintiff informed us that they took approximately 12,000 photos. The case material that we received from attorney Johnson included hundreds of these photos and videos, which were actually provided as evidence.

- Testimony of plaintiffs who saw the plastics in situ and "provided detailed, credible testimony regarding plastics discharged by Formosa" (Formosa ruling, VI, p. 8);

- Third-party testimony: The "Waterkeeper offered testimony of [other] interested citizens" (Formosa ruling, VI, p. 8), which supported their claims with photos and videos;

- The knowledge of three independent experts (two with PhDs), against which Formosa raised the Daubert standard for admissibility of scientific evidence. The Daubert standard is a framework for a judge to decide if evidence is credible, developed in the case Daubert v. Merrell Dow Pharmaceuticals. The court accepted the expert testimony as reasonable and credible;

- TCEQ findings of discharged plastics that the plaintiffs could easily request and access, on the basis of the Texas Public Information Act;

- Admissions of defendants' experts who viewed videos of the discharged plastics and agreed that the discharge was "more than trace amount;"

- Formosa documents and photos, including audits of their stormwater and wastewater system, as well as audits about ways to control plastics from being spilled. Formosa's own testing of plastics on the shores of Lavaca Bay was used by the plaintiffs to show that most of the plastics found there had the chemical signature of the company.
We also reviewed a copy of the Trial Exhibits List and the Plaintiffs' Amended Proposed Findings of Fact (shared by attorney Johnson), in which the methodology for identifying and collecting evidence of plastics discharge is documented (Proposed Findings of Fact, p. 74). We noted the admission of all evidence submitted by the plaintiffs.

The pictures, videos, and plastics-containing bags provided by the volunteers can qualify as citizen science, although the judge did not explicitly label them as such. The plaintiffs also engaged experts who intervened in the litigation as qualified expert witnesses for their professional background. However, no expert testimony was needed to lay a foundation for admission of the public evidence. The expert testimony was instead elicited to show that the plastics were not legacy plastics, i.e., they were not plastics discharged years ago that had somehow resurfaced.

Remarkably, neither the court nor the company's attorneys significantly challenged the data gathered by the citizens. The evidence at hand required data collection based on simple, direct observations or collection of plastic objects by hand, i.e., not involving further analyses. This can be seen as a form of citizen science as it involved gathering information on environmental conditions in an organized manner. The protocols followed were explained to us by one of the plaintiffs. First, the volunteers learned how to identify plastic waste, to distinguish it from other material found in the water, and to document it. When the plastic objects, photos, or videos were taken, the person collecting the data (or an accompanying person) also recorded the date and location, and sometimes the wind conditions. The plaintiffs kept record of what they found and regularly submitted the new material to the attorneys. Over time, they set up a chain of custody, defining from whom the piece of evidence was collected, who stored it, and to whom it was delivered. This accurate, structured plan of data collection was key to the admission and credibility of the public evidence.

The data collection was relatively simple and no particular training was required for the participants. Accordingly, it was not necessary to provide any evidence on training, and the material presented to the court was just "evidence of a fact, not part of a scientific study" (Amy Johnson, personal communication). There was also no sampling as such (although the text of the ruling uses the terms "plastic samples," e.g., Formosa ruling, VI, p. 8). This is because the term implies some scientific method to collect a statistically representative sample of a larger population, whereas in this case, the citizens were simply documenting hard, factual evidence, i.e., the presence of plastics in the water. As Johnson stressed, there was no need for scientific samples: the plastic instances documented were just "an example of the big picture;" they did not have to be "representative of a concentration, 
but proof of a base level violated" (Johnson, personal communication). The volunteers gathered presence data, or evidence of the fact that there were plastics in the water, rather than proof of quantity. The fact that a normal observer could see plastic in water was enough to satisfy the burden of proof that plaintiffs had. "If someone could easily see the plastics, we argued that this meant that more than a trace amount had been discharged," noted Johnson. "The only skill was having a good eye and the time to look for the plastic," affirmed one plaintiff (Plaintiff, personal communication). Although the observations did not require any specialization, over time, the citizens (one former shrimper, one former Formosa employee, and other local volunteers, who already had a good knowledge of the local situation) learned how wind and current could affect where the plastics would likely be found, and they refined their data collection.

Conceivably, more complex forms of citizen science, e.g., requiring detailed quantitative evidence to quantify the damage or prove causation, could have been more easily challenged in court-eventually under the Daubert standard. In fact, in the case at hand, the legal standard to be applied was a relatively simple. The amount and soundness of the submitted evidence was just too strong to be challenged. "How do you challenge a photo of plastics? It is hard evidence of those plastics," said the attorney (Johnson, personal communication). "[Formosa] did try to claim that some plastics might have come from a spill on a roadside or might have been plastics spilled on railroad tracks, but they did not have hard evidence of this or of how they would have been so close to the discharge outfalls" (Johnson, personal communication). This consideration suggests that the applicability of this case to more sophisticated types of public evidence may be limited.

\section{The settlement and the status of the case}

The declaratory judgment issued responded to the plaintiffs' claims. The court both considered past violations (monetary relief) and the risk of future violations (injunction). In the settlement between the parties that followed the ruling, Formosa agreed to monetary relief amounting to 50 million US dollars in mitigation payments. The parties agreed to a settlement and negotiated a consent decree, which they then presented to the court. The court endorsed this settlement by approving the consent decree and remedy. Thus, the ruling is now definitive, i.e., it cannot be appealed. The sum agreed will be paid over five years into a fund supporting projects that will help revitalize the local marine resources, public beaches, and waterways damaged by the company's operations (Impact Fund News 2019, also containing a detailed description of the fund allocation).
The plaintiffs informed us that they have now organized ${ }^{9}$ to implement the consent decree and to ensure that Formosa duly executes it. They thus changed their role and are acting as a watchdog in the reparation process. All plaintiff remediation monitoring activities were available to us, through attorney Johnson, in an appellate court exhibit. Furthermore, plantiffs are pushing for legal interventions to reach a zero-discharge plastic production (Hansen and Reddy 2020).

The Formosa case also inspired other (ongoing) citizen suits by environmental organizations (for example, Charleston Waterkeeper v. Frontier Logistics LP in South Carolina) that are forcing courts to define exactly what certain qualitative standards entail, and are pushing state agency enforcement. The case is also triggering other actions against Formosa subsidiaries, for example, in Louisiana where local residents are contesting the issuing of a permit. ${ }^{10}$ Conceivably, the case will affect all dischargers in Texas that produce or handle plastics. Especially in the plastics industry, the case is triggering a stronger regulatory response, and permits are already being rewritten to include an explicit zero-discharge limit (Hansen and Reddy 2020). Numerous grassroots organizations are demanding "no more nurdles" (No More Nurdles, 2021; Moore-Eissenberg 2019) in the production of plastics. ${ }^{11}$ For example, the Nurdle Patrol is an organization launched in 2018 for collecting plastic pellets in the Gulf of Mexico and is creating a national database of plastic discharges, which has potential for citizen-initiated lawsuits. ${ }^{12}$

\section{ANALYSIS: KEY DETERMINANTS OF THE CASE SUCCESS ON THE UNDISPUTED ADMISSION OF THE SUBMITTED EVIDENCE}

The ruling (Formosa ruling, IX, p. 15) devotes attention to admissibility aspects and evidentiary grounds. From the case analysis we have presented and from our communications with the plaintiffs and attorney Johnson, we conclude that the following aspects played a crucial role in ensuring the admission of the citizen-collected evidence:

\section{The nature of the evidence: The nature of plastic}

pellets, powder and flakes-small plastic objects that can be recognized and collected easily by anyone, even without any specialized knowledge-played an important role in the judge's decision. The simple but telling type of evidence, which could be tested against a simple standard ("floating debris more than trace amount"), and which clearly demonstrate violation, made the admission of public evidence much easier. This substantiates what was already noted in existing 
US studies of cases of citizen science in litigation (Emmett Environmental Law and Policy Clinic 2019, pp. 4, 5, 22, 31; Wyeth et al. 2019, p. 10,252, regarding the Potomac Riverkeeper case). Also, these studies found that courts are more willing to accept layperson testimony if the pollution can be perceived with unaided use of the senses of sight or smell, rather than if the evidence collection requires sampling or sensing with equipment or devices.

2. The quantity and time coverage of the evidence submitted: The 2,428 bags documenting plastic pollution collected by the plaintiffs for more than three years almost daily at Lavaca Bay, and hundreds of videos and photos documenting unlawful discharge made the "judge very impressed," (personal communication with plaintiff). This evidence was said by the judge to show "violations for each of the 736 days of discharges into Lavaca Bay" (Formosa ruling, XI, p. 17). There seems to be a granularity advantage (in terms of temporal coverage) that volunteered evidence can bring.

3. The evidence converged, and each piece strengthened another: The citizen-collected evidence was supported by plaintiffs' submitted expert opinions and by company and TCEQ evidence. Horizon Environmental Services, the cleanup crew hired by Formosa, also confirmed that more than trace amounts of plastics were being discharged. Furthermore, former employers of Formosa with key insider knowledge supported the plaintiffs and testified on the unlawful discharge, also showing pictures taken from inside the plant. In addition, the plaintiffs could exhibit a number of company's audits demonstrating that Formosa knew about the leakage of plastic pellets, powder and flakes. Lastly, agency (TCEQ) documentation included in investigation reports confirmed all these violations. This suggests that the citizen-collected data confirmed or complemented the available official data.

\section{Other key elements to success}

The plaintiffs' standing in the litigation was fundamental, i.e., they had an interest in the case that allowed them to submit the lawsuit in the first place. They managed to demonstrate (easily) that the defendant's discharge contributed to pollution impairing the plaintiffs' use of the water body, in line with existing case law (Texans United for a Safe Economy Education Fund v. Crown Central Petroleum Corp.). The court found that the damage was proven and evident, taking into account much broader concerns than those strictly limited to the plaintiffs' human rights. The court did not link the environmental harms to the right to health, the right to property, or to family life of the applicants, as is usually done in human rights-based environmental cases. Instead, it bypassed this anthropocentric approach by recognizing the recreational and aesthetic value of the environment as such, and assessing if and to what extent this value was damaged.

Interestingly, the plaintiffs also managed to demonstrate violation of their right to access environmental information. Even if it did not use a rightsbased discourse, the court noted that "the plaintiffs have also suffered injury, in fact, because they were unable to obtain information that Formosa was obligated to publicly disclose in a timely fashion," which is in line with a solid case law (Center for Biological Diversity, Inc. v. BP; Sierra Club, Inc. v. Tyson Foods, Inc.). Both federal and state statutes (33 USC. §1318(b) - Records and reports; inspections; Texas Water Code \$26.0151) require reports of permit violations by the permittee to be publicly available. In this regard, according to the judge, "Formosa totally failed and refused to comply with a known duty" (Formosa ruling, XI, p. 20). See Appendix 2: "Focus on Formosa's obligations as documented in the ruling," for an overview of the key duties of the company.

Other winning factors of the case seem to be the presence of a dedicated champion, i.e., a local resident, plaintiff, and former shrimper, who took on the battle against Formosa, and who managed to attract people's attention and support. The open-minded attitude of the court was also indicated to us as an important element. And finally, one of the plaintiffs told us that she considers it a key success factor that they could get free legal support of high quality from the Texas RioGrande Legal Aid, a nonprofit providing free civil legal services to low-income persons. Indeed, Texas RioGrande Legal Aid not only provided free legal aid offering to the plaintiffs a talented team of experienced lawyers - but also financed expert witnesses. These factors clearly contributed to the success of the case.

\section{Attracting media attention}

Our review of a number of (online) newspaper articles demonstrates a growing attention to cases such as Formosa (Ahmed 2019), and their implications for pushing the industry and the regulators towards a zero-discharge plastic production (Hansen and Reddy 2020; Sullivan 2020). We could not find media outlets speaking in support of Formosa. One plaintiff told us that Formosa mostly abstained from comments. On the basis of the media reactions analyzed, we conclude that media coverage clearly emphasized the citizen science nature of the evidence (which the court did not).

The Texas Observer, for example, reports a remarkable quote from attorney Johnson: "This is an instance where 
citizens collected evidence of violation of the Clean Water Act, and what's so powerful is that that was used to prove these thousands of violations" (Ahmed 2019). Other (online) media outlets (such Freeman 2019) stressed the groundbreaking potential of the ruling, and the great victory for the concerned citizens in terms of achieving social and environmental justice (Impact Fund News 2019).

Johnson also shared with us a rich list of media that covered the case before the 2019 ruling. Among them is the piece featured on Plastics Today with the telling heading, "Formosa Plastics Sued for "Significant, Chronic and Ongoing' Violations of Clean Water Act at Texas plant," (Plastics Today 2017) and The Guardian piece entitled "World's Largest Plastics Plant Rings Alarm Bells on Texas Coast." (Milman 2017). A full list of media coverage of the case can be provided upon request. Such a list was filed with the US Court of Appeals for the Fifth Circuit, and the entire filing is a matter of public record.

The overall situation suggests that media coverage was crucial to the plaintiffs' strategy. The San Antonio Bay Estuarine Waterkeeper managed to attract substantial media attention before, during, and after the ruling. This tactic seems promising for both providing larger social support to ongoing actions and mobilizing communities for future actions.

\section{CONCLUSION}

Despite the context-dependency limitations of our findings, this analysis allows us to respond to our preliminary and key questions, and to extract more generalizable lessons. In terms of the types of evidence that count as citizen science in the Formosa litigation, we can say that videos, pictures, and plastics-containing bags (collected by local residents and coordinated by a non-profit organization) represented citizen science data. Interestingly, in response to our question regarding how the judge classified this evidence, we can affirm that the judge did not label any of the provided evidence as citizen science. The judge considered the evidence for its reliability and robustness on the side of other evidence that was brought to the court's attention.

The fact that the court did not characterize the evidence as citizen science is not surprising because the term does not have any legal significance; judges typically look at fact evidence as simply evidence. The court just has to determine whether evidence from any source meets the standards of the Federal Rules of Evidence. On one hand, this can create uncertainty for the citizen scientists, as there is no specific set of rules expressly dedicated to citizen science evidence. On the other hand, this can be encouraging, as the court did not seem to be concerned about who presented the data.

The role played by the citizen-collected evidence in the judge's decision in this case seems complementary; it reinforces other evidence-some from the plaintiffs, some from the competent authority, and some from the company itself. The judge's written decision is brief when it comes to reasons for accepting the evidence, possibly in part because the citizens' evidence was not significantly challenged by the company's attorneys. However, we can affirm that it would help future cases if judges could provide better guidance on the standards they apply to citizen science. We would welcome a legal recognition at a procedural level of this peculiar category of evidence because it clearly presents some special traits in respect to other forms of (more traditional) evidence. From another viewpoint, specific standards for acceptability of citizen science data may not be needed considering the general application of the Federal Rule of Evidence and the Daubert standard. Guidance on a case-by-case basis and relative case law may help clarify how citizen science is handled by the court.

From the analysis developed above, we conclude that the hurdle of presenting citizen-collected evidence is lower where the process of gathering evidence is relatively nontechnical and based on ordinary observations, as opposed to processes using sophisticated techniques and instruments. The more sophisticated the sampling, the greater the likelihood the counterpart or the court may challenge the procedure for taking samples (e.g., its representativeness, or the sampling protocols).

Lastly, the Formosa case illustrates that the criteria courts apply to determine what counts as valid, legitimate, and authoritative evidence is based on specific subjective, spatial, and material considerations. From a subjective perspective, citizens (as potential plaintiffs) must demonstrate they are personally affected by the harms in question. Furthermore, from a geographic perspective, the evidence is inherently localized and spatially situated; the citizens are documenting specific harms that are personally affecting them in an identified local context. From a material standpoint, the civic evidence accepted by courts must be tangible or perceptible. The easier the proof of perception, the more likely the evidence is accepted.

Studies such as the one that we developed here can be useful for citizen science communities that wish to follow the steps of the San Antonio Bay Estuarine Waterkeeper. For future citizen scientists who wish to have their data considered in court rulings, we isolated the winning ingredients for admissibility in Table 2 below. 


\begin{tabular}{|c|c|}
\hline \multirow[t]{4}{*}{ Strategy } & Plaintiffs should rely on national and state law, and specific permits to ground their claims against a polluter. \\
\hline & Plaintiffs should find an established organization to represent them, and a free legal aid service (if they cannot afford the litigation costs). \\
\hline & $\begin{array}{l}\text { Only in the US, citizens can use the citizen suit authority provided by the Clean Water Act to directly sue the private company (but } \\
\text { only after having notified the state and competent authorities, and in case of their inaction). }\end{array}$ \\
\hline & Plaintiffs should attract media attention as it can give emphasis to the work of the citizen scientists and mobilize others. \\
\hline \multirow[t]{3}{*}{ Evidence } & Plaintiffs' evidence should show an environmental problem and ideally also pinpoint a lack of reporting by the company. \\
\hline & $\begin{array}{l}\text { The easier the collection process, the more likely the court will accept citizen-collected evidence without substantial disputing or } \\
\text { scrutiny. }\end{array}$ \\
\hline & Plaintiffs should rely on a combination of evidence, including both lay and expert, which either confirms official data or fills reporting gaps. \\
\hline
\end{tabular}

Table 2 Winning ingredients for the admissibility of citizen science data in court.

\section{STUDY LIMITATIONS AND SPARKS FOR FUTURE RESEARCH}

To draw applicable lessons for citizen-gathered evidence in litigation, it is important to note that some of this discussion is unique to the US legal system and may not hold elsewhere. For example, in the US, plaintiffs can sue a company to enforce permit terms without going through the state or the competent agencies (yet having to give a 60-day advance notice to the state and agencies to file the lawsuit; if they diligently prosecute the suit, citizens cannot sue), which in the Formosa case was the TCEQ; this is a peculiarity of the US Clean Water Act and will likely vary by country. Future research should analyze this matter in relation to other jurisdictions where it is also admissible for citizens to directly sue a private company for infringements of environmental regulations. For example, in Italy, only the State can sue companies for compensation for environmental damage, as a damage to the public interest, whereas all other parties, whether individuals or associations, can bring only a civil action to obtain compensation for pecuniary and non-pecuniary damage under an already-established criminal proceeding. The issue of standing is also specific to the US as other countries may not have such a requirement or may have different criteria. These are important points to bear in mind when we think about transposing lessons from the US to Europe or to other jurisdictions.

Furthermore, even within the US legal panorama, the case is quite unique, namely because of the wealth of evidence gathered by plaintiffs and the time-span covered, the total lack of company reporting, the failure of the competent agency, and the high settlement sum-the biggest settlement under the citizen suit authority ever litigated! (Fernandez 2019). This means that the lessons discussed here may not be extendable to other cases involving similar scenarios if they have lower availability of evidence. Nonetheless, cases such as Formosa could illuminate and inspire fellow communities striving to be heard in court on the basis of the evidence they collect.

We were also limited by the parties consulted. Whereas we engaged in a thorough exchange with plaintiffs that acquainted us with their evidence collection and submission process, we did not have the same exchange with the Formosa company. Future research may conduct an empirical inquiry into the company standpoint, which was not our focal point.

Through this analysis, we offer a starting point for citizen scientists to consider the potential that the data they gather can have in proving environmental wrongdoings. However, aware of the changing lessons for changing contexts, we consider our research still far from dictating success factors for a judicial uptake of citizen science. Future research should systematically screen existing cases that (somehow) used citizen-collected evidence, and identify patterns. Particularly useful would be an analysis of the extent to which traditional forms of evidence submitted before courts could be considered citizen science, and how such evidence is admitted. We deem that such research should be country-specific, considering the changing procedural law scenarios in different countries, yet bear in mind a comparative lens of analysis.

\section{NOTES}

1 Verbatim from the text of the ruling, Formosa ruling, XI, p. 17, "The evidence shows that Formosa has never reported a single discharge of floating solids to TCEQ."

2 The San Antonio Bay Estuarine Waterkeeper is an association established in 2012 under Calhoun County Resource Watch, which is a 501 (c)(3) nonprofit organization, funded in 1989. Plaintiff Diane Wilson is the founder and president of the Calhoun County Resource Watch, and also founder and executive director of the Waterkeeper.

3 More information on these organizations and research groups can be found at https://www.citizenscience.org/working-groups/lawpolicy-working-group/; https://www.eli.org/about-environmentallaw-institute; https://hls.harvard.edu/dept/clinical/clinics/emmettenvironmental-law-and-policy-clinic; https://www.epa.gov/. 
4 Actually, as a caveat, it should be noted that the plaintiffs plead the discharge of plastic powder in stormwater by Formosa, but the matter was not litigated in the trial. The term stormwater was used by the court in the text of the Formosa ruling. The wording storm water could also be used.

5 An example of this can be found in this video: https://www.youtube. $\mathrm{com} /$ watch?v=lq4YOrW4xE8\&feature=youtu.be.

6 For more information on the organization, see https://ec.europa.eu/ jrclen.

7 Dataset available at http://data.jrc.ec.europa.eu/dataset/jrccitsci-10004.

8 An ongoing Dutch Research Council (NWO) Rubicon project that started in summer 2020 and that will develop in a Marie Curie Individual Fellowship on the project titled "SENSJUSCitizen Sensing as a source of evidence in environmental justice litigation and as a tool for environmental mediation," https:// sensingforjustice.webnode.it/.

9 More information on their ongoing activities at https://www. nomorenurdles.org/.

10 More information at https://www.stopformosa.org/.

11 See, also advocating for a "Plastic Free Ocean," https://www. asyousow.org/our-work/waste/ocean-plastics.

12 More information at https://nurdlepatrol.org/Forms/Home/.

\section{SUPPLEMENTAL FILE}

The supplemental file for this article can be found as follows:

- Supplemental File 1. Appendices 1-5. DOI: https://doi. org/10.5334/cstp.367.s1

\section{ETHICS AND CONSENT}

The research project under which this study was developed was reviewed by the research ethics board (REB) of the European Commission's Joint Research Centre (JRC) on 26 August 2020. The Members of the REB concluded that the presented research activities would be conducted in compliance with fundamental ethical principles, and issued clearance on 29 August 2020.

\section{ACKNOWLEDGEMENTS}

We express our gratitude to the Editorial Team and to Anonymous Reviewers of the Citizen Science Theory and Practice journal for their valuable feedback in the preparation of this piece. A special acknowledgment is deserved by the spokesperson from the plaintiffs and their chief attorney, Amy Johnson, for engaging in insightful discussions on the case. Sincere thanks go to the two US citizen science and environmental law specialists that we consulted as experts in the field, for thinking along with us on the topics discussed in this article. Furthermore, we acknowledge the enriching talks that took place within the Citizen Science Association Law and Policy Working Group, at Tilburg Law School and at the JRC.

\section{FUNDING INFORMATION}

This research benefits from the support of the ongoing individual research grant of the Dutch Research Council NWO, the Rubicon fellowship n. 66202117.

\section{COMPETING INTERESTS}

None of the authors has any competing interests. This piece should be seen as reporting the findings of independent researchers analyzing the case. We do not represent the interest of one or the other party. We took as reference the written ruling and news items pertaining to the ruling. We have not been engaged in the suit in any way. Under recommendations of the Reviewers, we engaged in targeted communications with the plaintiffs and attorney Johnson to gather deeper information on the case and specifically on the evidence submitted.

\section{AUTHOR CONTRIBUTIONS}

Both authors contributed to the research design and methodological aspects of the manuscript. The first author took the lead in the writing process and in deploying the legal research.

\section{AUTHOR AFFILIATIONS}

Anna Berti Suman (D) orcid.org/0000-0002-8973-8436 The Tilburg Institute for Law, Technology and Society - Tilburg University, NL

Sven Schade (iD) orcid.org/0000-0001-5677-5209

The European Commission Joint Research Centre, IT

\section{REFERENCES LITERATURE}

Ahmed, A. 2019. Nurdle by nurdle, citizens took on a billion-dollar plastic company - and won. Texas Observer, 3 July [online access at https://www.texasobserver.org/nurdle-by-nurdlecitizens-took-on-a-billion-dollar-plastic-company-and-won/ last accessed 2 August 2020].

Becker, M, Caminiti, S, Fiorella, D, Francis, L, Gravino, P, Haklay, M, et al. 2013. Awareness and learning in participatory noise sensing. Plos One, 8(12): 1-12. DOI: https://doi.org/10.1371/ journal.pone.0081638 
Bio Innovation Service. 2018. Citizen science for environmental policy: development of an EU-wide inventory and analysis of selected practices. Final report for the European Commission, DG Environment under the contract 070203/2017/768879/ ETU/ENV.A.3.

Den Broeder, L, Lemmens, L, Uysal, S, Kauw, K, Weekenborg, J, Schönenberger, M, Klooster-Kwakkelstein, S, et al. 2017. Public health citizen science: perceived impacts on citizen scientists: a case study in a low-income neighbourhood in the Netherlands. Citizen Science: Theory and Practice, 2(1). DOI: https://doi.org/10.5334/cstp.89

Emmett Environmental Law and Policy Clinic. 2019. Using Citizen Science Evidence in Litigation - Draft Version. Harvard: Harvard Law School.

Environmental Law Institute. 2002. A Citizen's Guide to Using Federal Environmental Laws to Secure Environmental Justice [online access https://www.epa.gov/sites/production/ files/2015-02/documents/citizen_guide_ej.pdf last accessed 1 September 2020].

Fernandez, S. 2019. Plastic company set to pay $\$ 50$ million settlement in water pollution suit brought on by Texas residents. The Texas Tribune, 15 October [online access at https://www. texastribune.org/2019/10/15/formosa-plastics-pay-50-milliontexas-clean-water-act-lawsuit/l last access 4 April 2021].

Freeman, S. 2019. Nurdle patrol wins settlement from Formosa Plastics. Corpus Christi Business News, 6 December [online access at https://www.ccbiznews.com/news/nurdle-patrol-winssettlement-from-formosa-plastics last accessed 1 August 2020].

Gutiérrez, M. 2018. Maputopias: Cartographies of knowledge, communication and action in the big data society - the cases of Ushahidi and InfoAmazonia. GeoJournal, 1-20. DOI: https://doi.org/10.1007/s10708-018-9853-8

Haklay, M and Francis, L. 2018. Participatory GIS and communitybased citizen science for environmental justice action. In: Chakraborty, J, Walker, G and Holifield, R (eds.), The Routledge Handbook of Environmental Justice, 297-308. Abingdon: Routledge. DOI: https://doi.org/10.4324/9781315678986-24

Hansen, KM and Reddy, BR. 2020. Citizen Suits Lead the Way for Agencies on Plastics Enforcement. Bloomberg Law, 16 October, [online access at https://news.bloomberglaw.com/ environment-and-energy/citizen-suits-lead-the-way-foragencies-on-plastics-enforcement?fbclid=IwAROdFAB3b7VT ftH5vbK3j_OsusnDSdheOKkx-u2fEj5yoSQL3nKGxvU8j90 last access 10 May 2021].

Impact Fund. 2019. A victory for citizen science along the Gulf Coast: nurdles, zero discharge, and \$50M. Impact Fund News, 18 December [online access at https://www.impactfund.org/socialjustice-blog/formosa-settlement last accessed 18 July 2020].

Irwin, A. 2018. No PhDs needed: how citizen science is transforming research. Nature, 23 October [online access at https://www.nature.com/articles/d41586-018-07106-5 last accessed 18 July 2020]. DOI: https://doi.org/10.1038/d41586018-07106-5
Milman, 0. 2017. World's largest plastics plant rings alarm bells on Texas coast. The Guardian, 26 December [online access at https://www.theguardian.com/environment/2017/dec/26/ worlds-largest-plastics-plant-rings-alarm-bells-on-texas-coast last accessed 10 May 2021].

No More Nurdles. 2021. [online access at https://www. nomorenurdles.org/about/ last accessed 10 May 2021].

Plastics Today Staff. 2017. Formosa Plastics sued for "significant, chronic and ongoing" violations of Clean Water Act at Texas plant. Plastics Today, August 3 [online access at https://www. plasticstoday.com/sustainability/formosa-plastics-sued\%E2\%80\%9Csignificant-chronic-and-ongoing\%E2\%80\%9Dviolations-clean-water-act last accessed 10 May 2021].

Smith, B. 2014. Agency liability stemming from citizen-generated data. Policy Memo Series Vol 3. Washington, DC: The Wilson Center.

Sullivan, L. 2020. Big oil evaded regulation and Plastic Pellets Kept Spilling, 22 December [online access at https://www.wbur.org/ npr/946716058/big-oil-evaded-regulation-and-plastic-pelletskept-spilling last access 10 May 2021].

Wyeth, G, Paddock, L, Parker, A, Glicksman, RL and Williams, J. 2019. The impact of citizen environmental science in the United States. The Environmental Law Reporter 3(49): 10237-10263.

\section{CASE LAW}

Center for Biological Diversity, Inc. v. BP Case 6:17-cv-00047 Document 155 Filed on 06/27/19 in TXSD Page 19 of 21 20/ 21 America Production Co., 704 F.3d 413, 429 (5th Cir. 2015) citing FEC v. Atkins, 524 U.S. 11, 21 (1998).

Charleston Waterkeeper, et al. v. Frontier Logistics LP, No. 2:2020cv01089 - Document 40 (D.S.C. 2020).

San Antonio Bay Estuarine Waterkeeper, et al. v. Formosa Plastics Corporation, et al., Case 6:17-cv-00047, Document 155 filed on 06/27/19 [online access at https://docs.justia.com/cases/federal/ district-courts/texas/txsdce/6:2017cv00047/1445904/155 last accessed 20 January 2021].

San Antonio Bay Estuarine Waterkeeper, et al. v. Formosa Plastics Corporation, et al. Case 6:17-cv-00047, Final Consent Decree, Document 195-2 filed on 11/27/19.

Sierra Club, Inc. v. Tyson Foods, Inc., 299 F.Supp.2d 693, 703-706 (W.D. Ky. 2003) 25.

Texans United for a Safe Economy Education Fund v. Crown Central Petroleum Corp., 207 F.3d 789, 793 (5th Cir. 2000).

US Supreme Court, Daubert v. Merrell Dow Pharmaceuticals (1993) Case 509 U.S. 579, 23 ELR 20979 [online access at https://supreme.justia.com/cases/federal/us/509/579/ [last accessed 7 January 2021].

\section{LEGISLATION}

Clean Water Act/Federal Water Pollution Control Act, 33 US Code §§ 1251-1387 (1972).

Records and reports; inspections, 33 US Code \$1318(b) (1789). Texas Water Code §26.0151 (1977). 
TO CITE THIS ARTICLE:

Berti Suman, A and Schade, S. 2021. The Formosa Case: A Step Forward on the Acceptance of Citizen-Collected Evidence in Environmental Litigation? Citizen Science: Theory and Practice, 6(1): 16, pp. 1-13. DOI: https://doi.org/10.5334/cstp.367

Submitted: 22 September 2020 Accepted: 21 April $2021 \quad$ Published: 11 June 2021

COPYRIGHT:

(C) 2021 The Author(s). This is an open-access article distributed under the terms of the Creative Commons Attribution 4.0 International License (CC-BY 4.0), which permits unrestricted use, distribution, and reproduction in any medium, provided the original author and source are credited. See http://creativecommons.org/licenses/by/4.0/.

Citizen Science: Theory and Practice is a peer-reviewed open access journal published by Ubiquity Press.

\section{]u[ ə}

